\title{
Preliminary Qualitative Analysis on mtDNA in Astyanax fasciatus Populations Cuvier, 1819 (Teleostei; Characidae) Indicate Population Distinctiveness
}

\author{
Daniele Aparecida Matoso ${ }^{1}$, Cesar Martins ${ }^{2}$, Roberto Ferreira Artoni ${ }^{*}$ and Pedro Manoel \\ Galetti Jr $\mathbf{~}^{4}$ \\ ${ }^{1}$ Departamento de Genética Universidade; Federal do Paraná; 81531-990; Curitiba - PR - Brasil. ${ }^{2}$ Departamento \\ de Morfologia; Instituto de Biociências; Universidade Estadual Paulista Júlio de Mesquita Filho; Distrito de \\ Rubião Junior s/ $n^{o}$; 18618-000; Botucatu - SP - Brasil. ${ }^{3}$ Departamento de Biologia Estrutural, Molecular e \\ Genética; Universidade Estadual de Ponta Grossa; Av. Carlos Cavalcanti, 4748; 84030-900; Ponta Grossa - PR - \\ Brasil. ${ }^{4}$ Departamento de Genética e Evolução; Universidade Federal de São Carlos; Via Washington Luís, km \\ 235; C. P.: 676; 13565-905; São Carlos - SP - Brasil
}

\begin{abstract}
A preliminary qualitative analysis of genetic variability status in Astyanax fasciatus (Cuvier, 1819) from upper Tibagi River headwaters and Vila Velha State Park (VVSP) was carried out by enzymatic digestion (RFLP) of DLoop region from mtDNA. The results showed that Tibagi and VVSP populations were genetically different.
\end{abstract}

Key words: Neotropical fish; RFLP; conservation genetics

\section{INTRODUCTION}

Fish from the genus Astyanax are small characid, characterised by an extensive phenotypic and genetic diversity, likely related to their biological characteristics or even to the non-monophyletic status of the group (Morelli et al., 1983, MoreiraFilho and Bertollo, 1991, Garutti and Britski, 2000). The Vila Velha State Park (VVSP), located in the Tibagi River basin, is characterised by the presence of natural rocky formations assigned sinkholes dated from Pleistocene. These sinkholes are very deep collapsed-like rocks covered by a nearly $50 \mathrm{~m}$ freshwater column and populations of
Astyanax fasciatus are abundantly found inside the sinkholes. The aim of this work was to analyse the D-Loop mtDNA region from $A$. fasciatus by Restriction Fragment Length Polymorphism (RFLP) to assess the genetic variation those populations.

\section{MATERIAL AND METHODS}

Samples of 38 individuals of A. fasciatus, a neotropical freshwater fish, were taken from three sites of Vila Velha State Park and from one site in the main channel of upper Tibagi River (Figure 1).

*Author for correspondence: rfartoni@ pesquisador.cnpq.br 


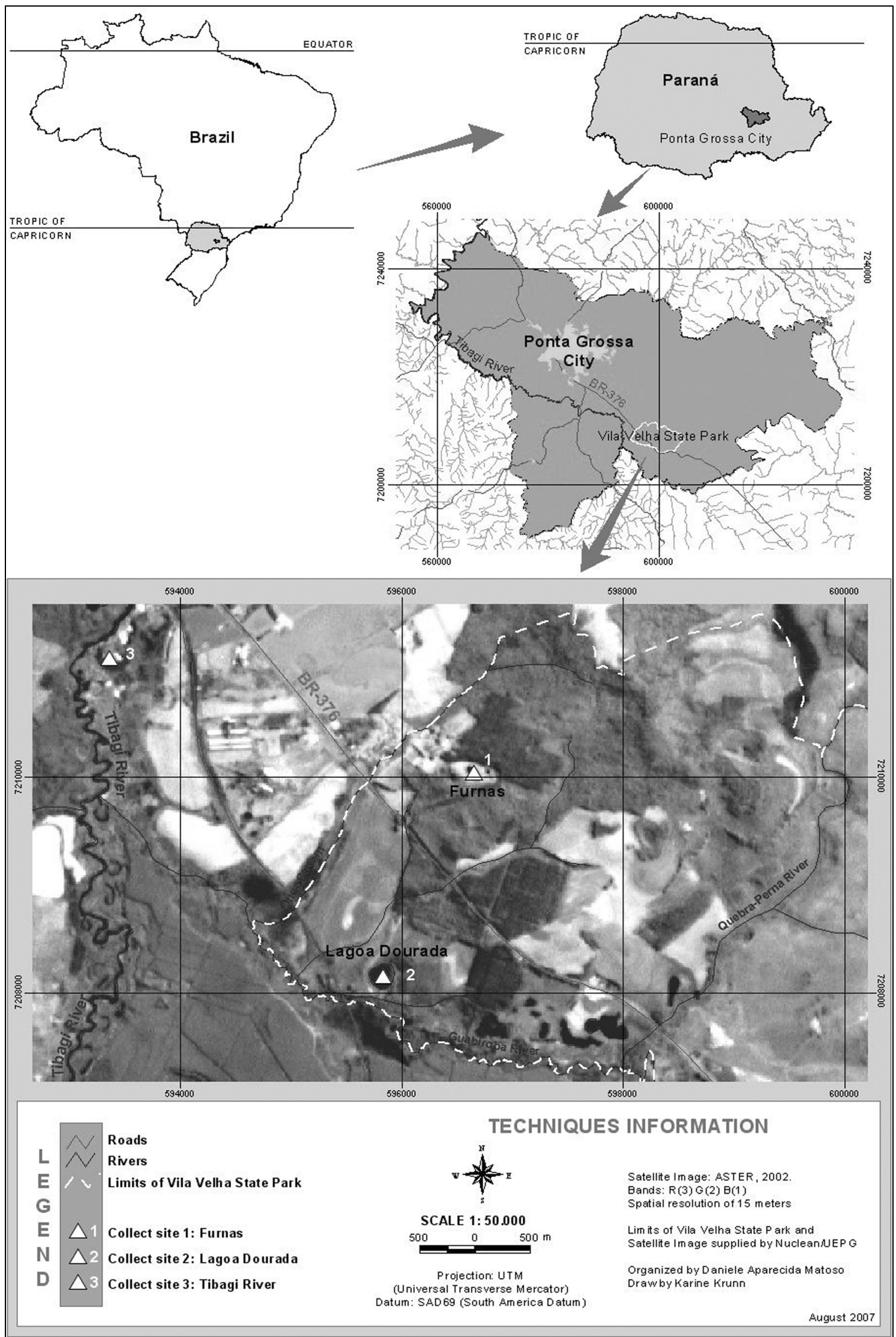

Figure 1 - Collect sites VVSP (Furna 1, 2 and Lagoa Dourada) and Tibagi River. 
These samples were used for DNA extraction following Sambrook et al., (1989). The control region mtDNA was amplified using primers FTTF 5' GCC TAA GAG CAT CGG TCT TGT AA 3' (forward) and F12R 5' GTC AGG ACC ATG CCT TTG TG 3' (reverse) (Sivasundar et al., 2001). PCR amplifications were performed in a final volume of $50 \mu \mathrm{l}$ containing $2 \mathrm{mM} \mathrm{MgCl} 2,2.5$ $\mathrm{U}$ of Taq DNA Polymerase, $200 \mu \mathrm{M}$ of each dNTPs, $4 \mu \mathrm{M}$ each primer, $1 \mathrm{x}$ buffer and $200 \mathrm{ng}$ of template DNA. Amplifications were carried out at the following conditions: pre-denaturation at $94^{\circ} \mathrm{C}$ for $5 \mathrm{~min}$ followed by 35 cycles denaturationannealing-elongation $\left(92^{\circ} \mathrm{C}, 1 \mathrm{~min} ; 50^{\circ} \mathrm{C}, 1 \mathrm{~min}\right.$; $70^{\circ} \mathrm{C}, 1 \mathrm{~min} 30 \mathrm{~s}$ ) and a final elongation step of $72^{\circ} \mathrm{C}$ for $5 \mathrm{~min}$. The enzymatic digestion from DLoop PCR amplified region was performed for all the samples (data not shown) with seven restriction enzymes randomly chosen: EcoRI, EcoRV, AluI, PvuII, RsaI, HaeIII, and ClaI, incubated overnight at $37^{\circ} \mathrm{C}$ in separated solutions in a final volume of $10 \mu \mathrm{l}$ containing $7 \mu \mathrm{l}$ of amplified DNA, $2 \mu \mathrm{l}$ of ultra pure water, $0.5 \mu \mathrm{l}$ of buffer solution, $0.5 \mu \mathrm{l}$ enzyme $1 \mathrm{x}(10 \mathrm{U} / \mu \mathrm{l})$. The digestion products were run in agarosis gel $2 \%$, 100 volts for 1 hour and stained ethidium bromide $(10 \mathrm{mg} / \mathrm{ml})$. The voucher specimens were deposited in the Museu de Zoologia of Universidade Estadual de Londrina (MZUEL 1792, 1794, 1795, 3735). The haplotypes were qualitatively organized according to the following phenotypes: $\mathrm{A}=$ absence of restriction site, $\mathrm{B}=$ presence of one restriction site, $\mathrm{C}=$ presence of two restriction sites, $\mathrm{D}=$ presence of three restriction sites (Fig. 2, Table I). Due to low number of individuals sampled $(\mathrm{N}=38)$ and also the disproportionate cross-section (2 specimens from Furna 1, 20 specimens from Furna 2, 5 specimens from Lagoa Dourada and 11 specimens from Tibagi River), no statistical test was performed to avoid any bias interpretation or mistaken conclusions.

\section{RESULTS AND DISCUSSION}

A DNA fragment of approximately $1.3 \mathrm{~Kb}$ was obtained after PCR amplification (Fig. 2). Two haplotypes were observed in the Tibagi population showing an intrapopulational variation. On the other hand, individuals from VVSP (Furna 1, Furna 2 and Lagoa Dourada) presented only one haplotype. Two possibilities could be considered concerning this result: there was a gain of new haplotypes among individuals from Tibagi River, and/or, the VVSP populations showed genetic structure due to founder effect (Table 1).

In a previous RAPD analysis a greater genetic similarity between the three VVSP populations was also observed when compared to Tibagi population, and it was suggested that in the main channel of the Tibagi River a superposition population might exist, while genetic drift might have occurred in the isolated VVSP populations (Matoso et al., 2004). The conservation status of A. fasciatus in the VVSP region must be concerned. Some years ago, the Furna 1 fish population was totally extinct due to eutrophization by droppings during the reproductive period of birds, resulting in the depletion of dissolved oxygen in column water. Thus, the remaining Furna 2 population characterised by genetic isolation could be considered endangered since they were restricted to the smaller sinkholes (Artoni and Almeida, 2001, Artoni and Shibatta, 2006). Population differentiation has already been revealed in other species of the genus Astyanax.

Sofia et al., (2006) found low gene flow and genetic divergence between A. scabripinnis from Cambé River basin. Similarly, Leuzzi et al., (2004) reported genetic divergence between the populations of A. altiparanae of Paranapanema River and concluded that it was necessary to consider such biological units for a whole conservation of this species. In the present study, results obtained with the enzymatic digestion from D-Loop mtDNA allowed to identify only few haplotypes for each locality. At present the causes of reduced number of haplotypes remained unknown. However possible causes for this reduced number of haplotypes could be related with several environmental and evolutionary factors such as the genetic drift during the VVSP sinkholes occupation, endogamic depletion by absence of gene flow among the populations of Furnas, positive selection or hitchhiking effect. These propositions are hypothesis that need to be better investigated in future studies using other genetics tools and also larger samples. Because fish population extinction was already registered 
in the VVSP area (Furna 1), and the Furna 2 and Lagoa Dourada populations also showed only one haplotype, it could be strongly suggested that these populations could be threatened and that genetic structure diagnoses should be helpful for needed conservation polices.

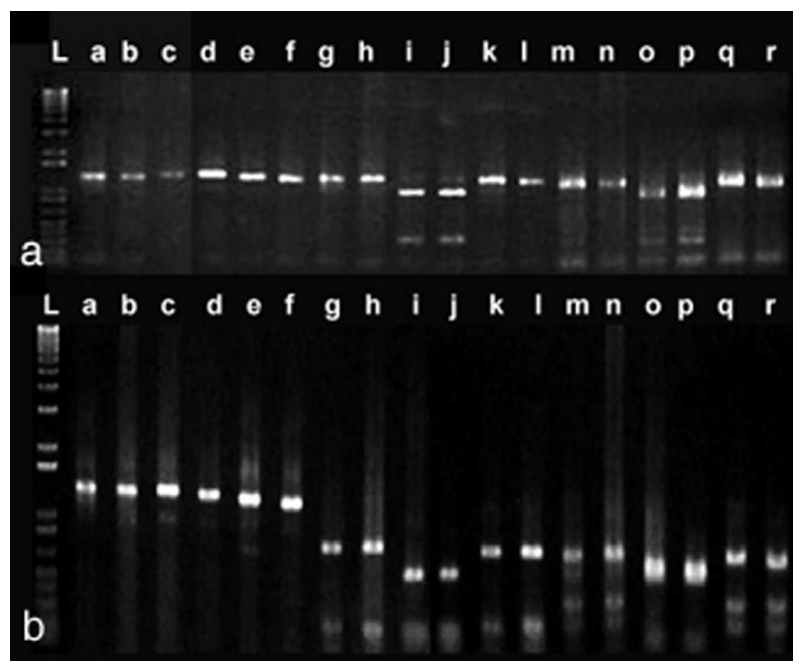

Figure 2 - Enzymatic digestion by RFLP of D-Loop mtDNA region of Astyanax fasciatus with approximately $1.3 \mathrm{~Kb}$. a) endonucleases $E c o R I(\mathrm{a}-\mathrm{f}), E c o R V(\mathrm{~g}-\mathrm{l}), A l u \mathrm{I}(\mathrm{m}-\mathrm{r}) . \mathrm{b})$ endonucleases PvuII (a - f), RsaI ( $\mathrm{g}-1)$, Hae III $(\mathrm{m}-\mathrm{r})$. Furna $1(\mathrm{a}, \mathrm{b}, \mathrm{g}, \mathrm{h}, \mathrm{m}, \mathrm{n})$; Tibagi River (c, d, i, j, o, p), Lagoa Dourada (e, f, k, l, q, r). L - ladder.

Table 1 - Haplotypes of D-loop mtDNA of Astyanax fasciatus. A) Absence of restriction site; B) Presence of one restriction site; C) Presence of two restriction sites, D) Presence of three restriction sites. $*$ Digestion not enforced. $\dagger$ Extinct population.

\begin{tabular}{ccccc}
\hline & \multicolumn{4}{c}{ Localities } \\
\cline { 2 - 5 } Enzyme & Furna 1 & Furna 2 & Lagoa Dourada & Tibagi River \\
\hline$E c o$ RI & $\mathrm{A}$ & $*$ & $\mathrm{~A}$ & $\mathrm{~A}$ \\
$E c o$ RV & $\mathrm{A}$ & $\mathrm{A}$ & $\mathrm{A}$ & $\mathrm{B}$ \\
$A l u \mathrm{I}$ & $\mathrm{A}$ & $*$ & $\mathrm{~A}$ & $\mathrm{~B}$ \\
$P v u \mathrm{II}$ & $\mathrm{A}$ & $\mathrm{A}$ & $\mathrm{A}$ & $\mathrm{A}$ \\
$R s a \mathrm{I}$ & $\mathrm{B}$ & $\mathrm{B}$ & $\mathrm{B}$ & $\mathrm{D}$ \\
$H a e \mathrm{III}$ & $\mathrm{C}$ & $\mathrm{C}$ & $\mathrm{C}$ & $\mathrm{D}$ \\
$C l a \mathrm{I}$ & $*$ & $*$ & $\mathrm{~A}$ & $\mathrm{~A} / \mathrm{B}$ \\
\hline
\end{tabular}

\section{ACKNOWLEDGEMENTS}

The authors thank Fapesp (Fundação de Apoio à Pesquisa do Estado de São Paulo) and CNPq (Conselho Nacional de Desenvolvimento Científico e Tecnológico) for financial support and IAP (Instituto Ambiental do Paraná) and IBAMA (Instituto Brasileiro do Meio Ambiente) for fish capture license in the Vila Velha State Park. The authors are also grateful to Dr. O. A. Shibatta for specimens identification and to M. A. Carvalho for laboratory assistance.

\section{RESUMO}

Uma análise qualitativa da variabilidade genética em Astyanax fasciatus (Cuvier, 1819) do alto Rio Tibagi e Parque Estadual de Vila Velha (PEVV) foi conduzida por digestão enzimática (RFLP) da 
região D-Loop do mtDNA. Os resultados evidenciaram que essas populações são geneticamente diferentes.

\section{REFERENCES}

Artoni, R. F. and Almeida, M. C. (2001), A singular diversidade dos peixes dos Campos Gerais: uma visão genética para abordagem conservacionista da região, pp. 505-518. In: Ditzel, C. H. M. and C. L. L. Sahr. (Org.). Espaço e Cultura: Ponta Grossa e os Campos Gerais. Ponta Grossa, Editora UEPG, 518 p.

Artoni, R. F. and Shibatta, O. A. (2006), Peixes do Parque Estadual de Vila Velha: aspectos da história natural, da biologia evolutiva e da conservação. Ponta Grossa, Editora UEPG, 153 p.

Garutti, V. and Britski, H. A. (2000), Descrição de uma nova espécie de Astyanax (Teleostei: Characidae) da Bacia do Alto Rio Paraná e considerações sobre as demais espécies do gênero na bacia. Comum. Mus. Ciên. Tecnol. PUCRS. Série Zoologia 13, 68-88.

Leuzzi, M. S. P.; Almeida, F. S. DE; Orsi, M. L. and Sodré, L. M. K. (2004), Analysis by RAPD of the genetic structure of Astyanax altiparanae (Pisces, Characiformes) in reservoirs on the Paranapanema River, Brazil. Genet. Mol. Biol. 27, 355-362.

MAtoso, D. A.; Artoni, R. F. and Galetti-Junior, P. M. (2004), Genetic diversity of the small characid fish
Astyanax sp., and its significance for conservation. Hydrobiologia 527, 223-225.

Moreira-Filho, O and Bertollo, L. A. C. (1991), Astyanax scabripinnis (Pisces, Characidae): a species complex. Brazil. J. Genet. 14, 331-357.

Morelli, S.; Bertollo, L. A. C.; Foresti, F.; MoreiraFilho, O. and Toledo-Filho, S. A, (1983). Cytogenetics considerations on the genus Astyanax (Pisces, Characidae). I. Karyotypic variability. Caryologia. 3, 235-244.

Sambrook, L. B.; Fritsch, E. F. and Maniatis, T. (1989), Molecular cloning: a laboratory manual, COLD Spring Harbor Laboratory Press, Cold Spring Harbor.

Sivasundar, A.; Bermingham, E. and Ortí, G. (2001), Population structure and biogeography of migratory freshwater fishes (Prochilodus: Characiformes) in major South American rivers. Mol. Ecol. 10, 407-417.

Sofia, S. H.; Silva, C. R. M.; Galindo, B. A.; Almeida, F. S.; Sodré, L. M. K. and Martinez, C. B. R. (2006), Population genetic structure of Astyanax scabripinnis (Teleostei, Characidae) from an urban stream. Hydrobiologia 553, 245-254.

Received: February 12, 2008; Revised: September 19, 2008; Accepted: August 26, 2009. 